Journal of Management and Economic Studies

2019, 1(8): 1-10 DOI: 10.26677/TR1010.2019.285

Journal Homepage: https://www.jomaes.org

\title{
The Impact of Employees Motivation on Performance of Communication Companies in Nigeria
}

\author{
B.A. Chukwu \\ Department of Business Administration, Igbinedion University Okada, Edo State, Nigeria \\ E. C. Kanu \\ Enugu State University of Science \& Technology Business School, Enugu, Nigeria \\ C.O. Osanebi \\ Department of Management Science, University of Nigeria, Enugu Campus, Nigeria
}

\begin{abstract}
This study investigated the impact of employee motivation on performance of communication companies in Benin City, Edo State, Nigeria. The ineptness of management to understand employees motivation and develop appropriate technique to manage it, is one of the problems facing many organizations in Nigeria today. And this has resulted to a great waste of human resources. Employees should be motivated to tap an immense source of their productive energy. Motivated employee is bound to internalize the goals of the organization and will be emotionally attached to it, since he perceive that management cares. A survey research design was used in this study. It involves collection of data to answer research questions and test of hypothesis. The data collected from the questionnaire instrument was analyzed using percentages and multiple regression. The research findings show that a significant and positive relation lie between the independent variables employee satisfaction, employee retention; employee productivity and employee efficiency and the dependent variable organizational performance. This is consistent with the literature. We recommend that organizations should understand the meaning of motivation and find an appropriate technique in handling it. They should identify the causes of employee de-motivation and develop a packaged programme to cater for the motivational needs of employees
\end{abstract}

Keywords: Motivation, De-motivation, Productivity, Satisfaction, Commitment, Organization, Employee.

\section{INTRODUCTION}

In communication companies which is fast changing like other industries too, employees are expected to demonstrate a very high performance in order to achieve the organizations missions, each year, as the growth and success of the organization is highly dependent on the sales and volumes of their products and services. Employees will not perform if they are not motivated by their employer. When compared to other companies, communication companies are well known 
with high workload. Pressure for innovation and stringent time frame, which can be a major reason for workers to be motivated to enhance productivity and stick to their job.

The ineptness of management to understand employees motivation and develop appropriate technique to manage it, is one of the problems facing many organizations today in Nigeria and this has resulted in a great waste of human resources. De-motivated employee is not bound to internalize the goals of the organizations and be emotionally attached to it because he perceives that management does not care. Organizations should be able to satisfy the human resource component, which serves as the mind of the organization. The fulfillment of motivational needs by the organization result to employee satisfaction and enhances productivity and organizational effectiveness. Conversely the neglect of motivational needs de-motivates an employee, and result in employee dissatisfaction, which reflects in high turnover, frequent strikes, negative response, deterioration in employees job performance, poor quality, internal friction, walkout, increasing wastage, threat to down tools, rumour mongering, employee generated petition to management, frequent complaints, absenteeism, and tardiness (Steer \& Porter, 1991).

In order to avoid the aftermaths of de-motivating employees, management should identify the causes and develop a package programme to cater for the motivational needs of employees. For an organization to be effective, it must come to grips with the motivational problems of stimulating both the decision to participate and the decision to produce at work. Organizations should see motivation as a catalyst to enhance productivity. They should avoid employees demotivation and identify problem and causes of de-motivation and develop a way of salvaging the situation. Organization should be able to produce the atmosphere for best work performance. Workers should be motivated to foster feeling of achievement, responsibility, growth and earn recognition in case of challenging work (Herzberg, Mauser \& Syderman, 1959).

Employees are motivated when the economic need of the organization is equitably distributed. Employees are very conscious of equity pay. Employees should be paid what they are worth on the open market and not what the corporate guideline dictates. Employees not paid relative to their work will quit and seek employment opportunities where they may feel better compensated for their skills and attributes they possess (Brerz \& Thomas, 1992; Decomick \& Bachman, 2005). Motivating employee is perhaps the most intricate of management functions in any organization, whether in the public or private sector. If management were to have complete mastery of this important function, it would be very easy to get employees to perform exactly according to plans and design. Unfortunately, this has not been the case anywhere, because it is not possible to determine with any degree of exactitude what motivates a person at any given time. It is for this reason that many theories of motivation have been proposed with the hope that along the line the right cord may be struck to achieve the desired objective. Motives can be inferred, they cannot be seen. One has to investigate to determine what motivates and de-motivates people at work and the problems associated with de-motivation. It is through this process that demotivation of employees can be avoided and employee motivated to enhance productivity and organizational effectiveness (Hellriegel, Slocum \& Woodman, 1998).

Few decision area are more important than the areas of employee motivation. The research and effort devoted to recruitment, training and replacement as well as careful design of jobs and systems will eventually be wasted if the employees cannot be motivated to contribute his effort with high degree of willingness.

There are many theories concerning human motivation in industry, but unfortunately, there is little empirical evidence to support them. This is one of the reasons why this research was undertaken with the task of determining condition within the employment relation which contributes to employee motivation and the attendant effect on the organization. Of course 
individual differences must be taken into consideration as different persons have different wants and needs and will therefore be differently motivated in varying situations. The researchers must look for what motivates employees and use these as basis for structuring incentive programme, that will enhance employee motivation. Furthermore, the contribution to the literature is that the study has incorporated the impact of motivation as independent variables in the model of study in other to view the impact of these variables on organizational performances.

\section{Objectives of the study:}

This study attempts to determine the impacts of motivation on organizational performance. In specific terms, the objective of the study are:

i. identify the extent employee satisfaction affects organizational performance

ii. ascertain the extent employee retention affects organization performance

iii. establish the extent employee productivity affects organizational performance

iv. determine the extent employee efficiency affects organizational performance

\section{Statement of Hypotheses:}

The following null hypotheses were formulated to guide this study

Ho1 Employee satisfaction does not positively affect organizational performance

Ho2 Employee Retention does not positively affect organizational performance

Но3 Employee productivity does not positively affect organizational performance

Ho4 Employee efficiency does not positively affect organizational performance

\section{LITERATURE REVIEW}

Motivation is a human process that is initiated by the emergence of a need, which drives an individual into expecting something of goal-object, while a task is performed. A reward is obtained as a result of this, and when the obtained reward is equal to the expected reward, the individual is said to be satisfied. Motivation is self-initiated and influenced by the action of others. A highly motivated staff provides the better services that will lead to customer satisfaction (Edegbe, 2006).

Motivation has been defined in several ways. However, Stone and Wenkel (1988) and Umobuiarie (2009) defined motivation as that which causes, channels and sustains people behavior. Motivation is also defined as the internal psychological process of initiating, energizing, directing and maintaining goal directed behavior. Nwankwo (1991) argued that the more the needs of workers are satisfied within the organization, the more they are motivated to do their work and also satisfy the need of the organization.

Nowadays new social forces brought by industrial revolution has shown that many of the more intrinsic motivation factors are replaced by more extrinsic factors. Workers are more interested in the extrinsic motivational factors and pursue their best economic interest. They become demotivated when these extrinsic factors especially money is not attached to their motivational need. A topic of motivation is important in order to comprehend more fully the effect of variations on other factors (such as job satisfaction, job performance, organizational commitment, job design, leadership system), as they relate to performance. Akinmayowa (1993) opined that a relationship exist between motivation, satisfaction and efficiency. He argued that most people would be motivated to produce more goods and more efficient in providing services, if their job 
make them achieve some social and psychological needs. A motivated employee holds positive attitude to work, while a de-motivated employee holds negative attitude.

For an organization to be effective, it must come to grips with the motivational problems of stimulating both the decision to participate and the decision to produce at work. The most important of employees maintenance need is economic. They seek employment to cater for their economic need, such as food, shelter, cloth, etc. Organizations can satisfy these needs by paying competitive wages and salaries, salary reviews, enhanced allowance and benefits (Brech, 1975; Thierauf, Klekamp \& David, 1997). This will go a long way to enhance productivity and organizational commitment. Given a chance of self-fulfillment through conditions that could aid the individual goals of prestige, participation in decision making machine of organization in which he works, economic and employment security, the passive instrument inherent in the employee will be invoked, and this will cause the worker to be more productive and more receptive to direction (Elanyne, 2004)

Employee are strongly motivated, when they perceive equity pay. They become dissatisfied when their pay is not competitive, and also, when there is absence of security needs and conducive work atmosphere (Hicks \& Ray, 1981; Kepner,1993). Employees are not satisfied and committed, when inequity exists. Inequity exists when the ratio of outcomes to inputs are unequal. Tension is not pleasurable, so a person is motivated to reduce it to a tolerable level (Adams, 1963). People may either increase or decrease their inputs to what they feel is an equitable level. For examples underpaid people reduce the quantity of their production, work shorter hours, be absent more frequently (Bretz \& Thomas, 1992). People may distort their inputs and outcome when there is inequity. People may mentally distort them to achieve a more favourable balance. For example people who feel inequitably treated may distort how hard they work (Hellriegel et al, 1998 Bretz \& Thomas, 1992).

Mba and Ikemefuna (2012) in their study, found that motivation increase positive outcomes, such as job satisfaction, commitment and performance, and can decrease absenteeism and turnover. Employee de-motivation can ensue, when job dissatisfaction arise from low salary, poor benefits, lack of job security, poor recognition and lack of job flexibility in schedule (Albaugh, 2003). This can lead to low productivity.

Adeyemo and Afolabi (2007) argued that the higher the level of job satisfaction as a result of motivation, the lower the intention to turnover, and the higher the commitment. Elanyne (2004) argued that cutting down employee motivation in economic or monetary terms does not translate to higher profit, since one must also take productivity and quality into account. Most organizations compensation policy illustrate this. Some organizations chose to pay above average wages and provide its employees with free health coverage. Management assumption is that if they care for their employees, they will take care of their customer. This pay strategy seems to be working in most organizations. A lot of profit is being generated through this motivation principles and increase retention figure of employee also.

An organization that is productive oriented would have to device means to ensure that a worker has chance of moving from his position at the point of entry to higher one in the hierarchy. In this way, the worker will be strongly committed to the goal of the organization and be emotionally attached to it, because he now perceive that management cares (Maura, Igor \& Adalgisa, 2011).

Employees are dissatisfied when their maintenance and motivational needs are neglected by management. The consequences of this action of management result in low productivity, low commitment, labour turnover, absenteeism, tardiness, frequent complaints, threat to down tools, 
increasing wastage, internal friction, rumour mongering, employee generated petitions against management, strikes, walkout and deterioration in employee performance (Steer \& Porter, 1991)

Employees can be de-motivated when they perceive lack of organizational support, emotional exhaustion and burnout (Barvey Obst \& Sheeham, 2004); Bokiti \& Talib, 2009). The ineptness of management to understand employee motivation and develop appropriate techniques to manage it has resulted in a great wastage of human resources. A motivated employee is bound to internalize the goals of the organization and be emotionally attached to it, because he perceives that management cares. Managers who find the key to their employees inner motivation can tap an immense source of their productive energy.

\section{METHODOLOGY}

Survey research design was used to gather information from sample of communication workers of MTN; Globacom, Celtel and Etisalat in Benin City, Edo State. These communication outfits were selected for the study because they are ideal of companies that should be well motivated because of high workload, pressure or innovation and stringent time frame attached to the work. A non-probability purposive sampling technique was used in this study due to various limitations. So the sample was based on non-probability data.

A total of 250 questionnaire were distributed to these communication companies, and out of these questionnaires 151 questionnaire were retrieved and processed in this study. This represents $60.4 \%$ of response rate. The questionnaire was made up of 5 points Likert scale. For each variables, there were four (items/elements) which were deployed keeping in view the questionnaire filling culture and understanding of the population. The questionnaire is a combination of adaption and self development of items. The demographic data was part of the questionnaire. The reliability coefficient of the questionnaire was checked through Chronchbach's Alpha which is over all .793. It shows that the data retrieved through the questionnaire is reliable and could be used for analysis. There are five variables in total in the model, where there are four independent variables and one dependent variable. The independent variables are employee satisfaction, employee retention, employee productivity and employee efficiency and one dependent variable, organizational performance. As the data consists of single dependent variable and multiple independent variables, regression analysis were deployed and SPSS 16.0 was used to generate results. Descriptive method of analysis were used to analyze data from the questionnaire instrument using percentages. Hypothesis testing were carried out using multiple regression statistics.

\section{Model of Specifications}

In order to determine the impact of motivation on organizational performance, a multiple regression model is used. The regression model use is specified as follows:

$\mathrm{OP}=\beta_{o}+\beta_{i} \mathrm{ES}+\beta_{2} \mathrm{ER}+\beta_{3} \mathrm{Ep}+\beta_{4} \mathrm{EE}+\mu$.

Where

$\begin{array}{lll}\mathrm{OP} & = & \text { Organizational Performance } \\ \beta_{1} \mathrm{ES}= & \text { Employee satisfaction } \\ \beta_{2} \mathrm{ER}= & \text { Employee Retention } \\ \beta_{3} \mathrm{EP}= & \text { Employee Productivity } \\ \beta_{4} \mathrm{EE}= & \text { Employee Efficiency } \\ \beta_{0}= & Y \text {-intercept of the line }\end{array}$


$\beta_{\mathrm{i}}=(\mathrm{i}=1,2,3,4)$ are estimates of the coefficient

$\mu \quad=\quad$ An error term measuring variation in turnover intention

unaccounted for by the independent variables

DATA PRESENTATION AND ANALYSIS OF RESULTS

Presentation of data collected and used for Regression Analysis.

Table 1: Distribution of responses to questions on independent variables.

\begin{tabular}{|l|l|l|l|l|l|}
\hline \multicolumn{7}{|c|}{ Responses } \\
\hline $\begin{array}{l}\text { Independent } \\
\text { Variables }\end{array}$ & $\begin{array}{l}\text { Strongly } \\
\text { Agree }\end{array}$ & Agree & Undecided & Disagree & $\begin{array}{l}\text { Strongly } \\
\text { Disagree }\end{array}$ \\
\hline ES & $58(38.4)$ & $61(40.4)$ & $6(4.0)$ & $10(6.6)$ & $16(10.6)$ \\
\hline & & & & & \\
\hline ER & $43(28.5)$ & $59(39.1)$ & $8(5.3$ & $18(11.9)$ & $23(15.2)$ \\
\hline & & & & & \\
\hline EP & $69(45.7)$ & $50(33.1)$ & $4(2.6)$ & $12(8.0)$ & $16(10.6)$ \\
\hline & & & & & \\
\hline EE & $48(31.8)$ & $67(44.4)$ & $9(5.9)$ & $13(8.6)$ & $14(9.3)$ \\
\hline
\end{tabular}

Source: Field Survey 2016

Where:

$\begin{array}{lll}\mathrm{ES} & = & \text { Employee Satisfaction } \\ \mathrm{ER} \quad= & \text { Employee Retention } \\ \mathrm{EP} \quad= & \text { Employee Productivity } \\ \mathrm{EE} \quad=\quad \text { Employee Efficiency }\end{array}$

Figures that are not in bracket in table 4.1 show the number of responses, while those that are in bracket show the percentage of responses

Table 2: Distribution of responses questions on dependent variable.

\begin{tabular}{|l|l|l|l|l|l|}
\hline \multicolumn{7}{|c|}{ Responses } \\
\hline $\begin{array}{l}\text { Independent } \\
\text { Variable }\end{array}$ & $\begin{array}{l}\text { Strongly } \\
\text { Agree }\end{array}$ & Agree & Undecided & Disagree & $\begin{array}{l}\text { Strongly } \\
\text { Disagree }\end{array}$ \\
\hline $\begin{array}{l}\text { Organizational } \\
\text { Performance }\end{array}$ & $65(43.1)$ & $47(31.1)$ & $15(9.9)$ & $19(12.6)$ & $5(3.3)$ \\
\hline
\end{tabular}

Source: Field Survey 2016

Figures that are not in bracket in Table 2 Shows the number of responses, while those that are in bracket show the percentage of responses.

\section{Analysis of Data}

Table 3 Multiple Regression Result

\begin{tabular}{|l|l|l|l|l|}
\hline \multicolumn{5}{|l|}{ Dependent Variable: Organizational Performance } \\
\hline Variable & Coefficient & Std. Error & T-Statistics & Probability \\
\hline Constant & 1.120 & .249 & 4.687 & .000 \\
\hline ES & .453 & .069 & 6.531 & .000 \\
\hline
\end{tabular}




\begin{tabular}{|l|l|l|l|l|}
\hline ER & .310 & .057 & 5.398 & .000 \\
\hline EP & .601 & .050 & 11.925 & .003 \\
\hline EE & .306 & .049 & 6.238 & .001 \\
\hline
\end{tabular}

Statistical Package for Social Science (SPSS) Version 16.

$\begin{array}{lll}\mathrm{R} \text { Square } & = & .641 \\ \mathrm{R} \text { Square Adjusted } & = & .638 \\ \text { Std Error } & = & .412 \\ \text { T-Statistics } & = & 33.055(0)\end{array}$

\section{Interpretation of Results:}

\section{Test of Hypotheses}

Hypothesis 1: Employee satisfaction does not positively affect organizational Performance.

The beta value shows that 1 unit positive change in value of employee satisfaction (ES) would result in 0.453 units $(45.3 \%)$ positive change in organization performance; other variables being held constant. This in essence entails that employee satisfaction (ES) is a function of organizational performance. Employee satisfaction (ES) shows statistical unique contribution in explaining organizational performance $(\mathrm{P}<.01)$ while the $\mathrm{t}$-statistics of employee satisfaction also accounted for significant positive variation in depended variable, that is organizational performance $(\mathrm{t}=6.531, \mathrm{P}<.01)$. Resultantly null hypothesis is rejected and alternative hypothesis is accepted. Meaning that employee satisfaction (ES) exert significant effect on organizational performance and have positive relationship with organizational performance. This result align with the theory which states that employee job satisfaction is strongly associated with high level of organizational commitment, job performance and organizational well being. Employees are satisfied when properly motivated. Satisfied employees are known to show high level of work performance in the organization.

Hypothesis 2: Employee retention does not positively affect organizational performance.

The beta value shows that 1 unit positive change in the value of employee retention (ER) would result in .310 units (31\%) positive change in organization performance, other variables being held constant. This in essence entails that employee retention (ER) is a function of organizational performance. Employee retention (ER) shows statistical unique contribution in explaining organizational performance $(\mathrm{P}<.01)$, while t-statistics of employee retention (ER) also accounted for significant positive variation in dependent variables that is organizational performance $(t=5.398<01)$. Resultantly null hypothesis is rejected and alternate hypothesis is accepted. Meaning that employee retention (ER) exert significant effect on organizational performance and have positive relation with organization performance. This result accords with the theory which states that employees are likely to stay and be loyal and committed to the organization if properly motivated. Employees will retain their job and will be attached to the organization when properly motivated and will not like to turn over.

Hypothesis 3: Employee productivity does not positively affect organizational performance

The beta value shows that 1 unit positive change in the value of employee productivity (EP) would result in .601 units $(60.1 \%)$ positive change in organizational performance other variables being held constant. This in essence entails that employee productivity $(\mathrm{P})$ is a function of organizational performance. Employee productivity (EP) shows statistically unique contribution in explaining organizational performance with $(\mathrm{P}<.01)$. While the $\mathrm{t}$-statistics of employee 
productivity (EP) also accounted for significant positive variation in dependent variable, that is organizational performance $(t=11.925,<.01)$. Resultantly null hypothesis is rejected and alternate hypothesis is accepted. Meaning that employee productivity exerts significant effect on organizational performance. This results agrees with the theory which states that a motivated employee is bound to internalize the goals of the organization and be emotionally attached to it since he perceives that management cares. Motivation enhances productivity and performance of employee.

Hypothesis 4: Employee efficiency does not positively affect organizational performance.

The beta value shows that 1 unit positive change in the value of employee efficiency (EF) would result in .306 units $(30.6 \%)$ positive change in organizational performance, other variables being held constant. This in essence entails that employee efficiency (EF) is a function of organizational performance. Employee efficiency shows statistically unique contribution in explaining organizational performance with $(\mathrm{P}<.01)$; while the $\mathrm{t}$-statistics of employee efficiency $(\mathrm{EF})$ also accounted for significant positive variation in dependent variable, that is organizational performance $(\mathrm{t}=6.238, \mathrm{P}<.01)$. Resultantly null hypothesis is rejected and alternate hypothesis is accepted. Meaning that employee efficiency exerts significant effect on organizational performance by compelling them to ensure realization of organizational goals and performance.

\section{Discussion of Findings:}

Considering the results in table3, the individual coefficient $\beta$ in case of each and every variable indicates positive result over all.

Positive relation lies between the independent variable employee satisfaction and the dependent variable organizational performance. This result is consistent with the researches of Nwankwo (1991), Albaugh (2003), Mba and Ikemefuna (2012)

Positive relation also exists between the independent variable employee retention and dependent variable organizational performance. This result is consistent with the researches of Mba and Ikemefuna (2012)

There is a positive relation between the independent variable employee productivity and the dependent variable organizational performance. The result is also consistent with the research of Akinmayowa (1993)

The whole analysis show that the independent variables, employees satisfaction, employee retention, employee productivity and employee efficiency regress the dependent variable and provides considerable outcome, where significance value $(\mathrm{p})$ is less than $.001, \mathrm{~F}$ value is equal 33.055 and the $R$. Square is greater than 0.60 , while less than 1 value is observed from the standard error. $\mathrm{R}^{2}$ shows that the model is a fit one. $\mathrm{F}=33.055$ (.001) shows that the model has overall significance at $10 \%$ level. $\mathrm{R}^{2} .641$ suggest that the model has a good fit. This indicates that $64.1 \%$ of variation in organizational performance is accounted for by variations in explanatory variables, suggesting that the model has a good explanatory power on the changes in organizational performance among variables.

\section{CONCLUSION}

It is concluded that the predictor variables employee satisfaction, employee retention, employee productivity and employee efficiency positively affects organizational performance in telecommunication companies. All the variables have statistical significance t-ratio. The results are consistent with the literature.

Recommendations: 
Recommendations based on research findings:

1) We recommend that organizations should understand what is meant by motivation and the appropriate technique in handling it. They should identify the causes of de-motivation and develop a packaged programme to cater for the motivational needs of employees

2) Organizations should view motivational issues with seriousness and provide the necessary incentives such as competitive salary, regular salary, salary review, enhanced allowances and benefits to spur production and performance.

3) Organizations should adopt equitable salary structure and pay what obtains in the labour market, and not what the corporate guide line dictates.

4) Organizations should refrain from cutting down employee motivation in economic or monetary term since it does not translate to high profit. They should take productivity and quality into account.

\section{LIMITATIONS AND FURTHER RESEARCH}

Most of the review literature on employee motivation is not focused in Nigeria. There is paucity of literature on the impact of motivation on organizational performance in Nigeria. Nigeria Authors should endeavour to execute research in Nigeria environment, when studying employee motivation, so that future researchers can see where to base their argument and also contribute in building meaningful literature for further researches. Furthermore one of the limitations of this study was delay in returning the questionnaire by respondents. There was an assumption that respondents would complete the questionnaire correctly and in true and fair view without any form of bias, but it is not always the case, as error is introduced through lack of knowledge of subject matter and paucity of information. Error of $0.05 \%$ to determine sample size had its own limitation. Refusal to return questionnaire could be another source of constraint, because no data can be obtained without respondents cooperation and perseverance.

In its scope this study centered on service industry. It is hoped therefore that future research be carried out using manufacturing industry. The impact of employee motivation in food and beverage industry will be studied. The study will be wider in scope in terms of issue and geographical areas covered. It will permit wider generalization and also will be useful in confirming and rejecting existing findings on issue under study.

\section{REFERENCES}

Adam, J.S. (1963). Toward an understanding of inequity. Journal of Abnormal and social psychology, 67,442-436

Adeyemo, D.A \& Afolabi, J.O (2007) Influence of sexual harassment, occupational stress, emotional intelligence and job satisfaction in withdrawal cognition of female practitioners in Oyo State Nigeria. Pakistan Journal of Social Science, 4, 639-646

Akinmayowa, J.T. (1999). Man in organization. Nigeria Management Consultancy Forum. Educational Resource Centre, Benin City

Albaugh, J. (2003) Keeping Nurse in Nursing the profession challenge for today. Urologic Nursing, 23, 193-199 
Bokti, N.L.M. \&Talibi, M.A. (2009). A preliminary study of occupational stress and job satisfaction among male navy personnel at a Naval Base in Lumui, Malaysia.The Journal of international social research, 2, 299-306.

Brech, C.F. (1975). Principle and practices of management London Longman publishing co. Ltd.

Bretz, R. \& Thomas, S. (1992). Perceived inequity, motivation and final arbitration in major league base-ball. Journal of Applied Psychology, pp 280-299

Davey, J. Obst, P. \& Sheeham.M. (2001). Demographic and workplace characteristic, which add to the prediction of stress and satisfaction within the police workplace. Journal of Police and Criminal Psychology, 16, 29-39.

Edegbe, G.N. (2006). Motivation, satisfaction and efficiency in computerized organization. Nigerian Journal of Business Administration, University of Benin, Nigeria

Elanyne, R.D. (2004). Two refuse to join the race to the bottom for benefit and wages. Workforce Management, p.34

Helriegel, D. Slocum .J.W. \&Ivancevich M. (1987).Organizational Behaviour. Southwest College Publishing Cincinati, Ohio U.S.A.

Herzberg, F. Mauser B \&Syderman B, B (1959).The motivation to work. 8ed chapman and Hull Publishing Co. Ltd.

Hicks. H.G. \& Ray, C.G. (1981). Management New Yourk: M C GrawHill Book Co.

Decomic, J \& Bachman, J (2005). An analysis of turnover among retail buyers. Journal of Business Research, 58, 814-882.

Kepner, J (1983). A Hand Book of Management, Middle Sex: Penguin Books Ltd.

Mba, S.E. \&Ikemefuna, C.O. (2012). Job satisfaction and employees turnover in total Nigeria Plc in Lagos. Journal of Humanities and Social Science 21, 275-287.

Maura. G, Igor, P. \& Adalgsia, B. (2011). Intrinsic Motivation in the Italian health care. The mediating role of effective commitment. Journal of Management Research. Vol. 3 No 2.

Nwankwo, G. O. (1991. Banking Management Principle and Practice. Malthouse Press Ltd, Lagos.

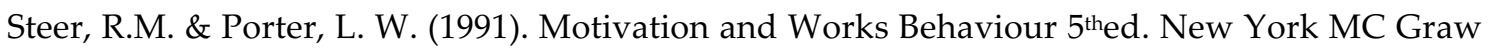
Hill.

Stoner, J. \&Wankel, C (1988). Management 3rded, Prentice Hall India, New Delhi.

Thierauf, R. Klekamp, C. \& David, W.G. (1997). Principles and Practices of Management New York John Willy and Sons publishing Co. 